\title{
Mapping Hydrothermal Alteration Targets from Landsat 8 OLI/TIRS and Magnetic Data Using Digital Image Processing Techniques in Garoua, North Cameroon
}

\author{
Quentin Marc Anaba Fotze ${ }^{1,2, *}$, Anatole Eugene Djieto Lordon ${ }^{1}$, Joseph Penaye ${ }^{2}$, \\ Jean Paul Sep ${ }^{2}$, Mary Immaculate Neh Fru ${ }^{1,2}$ \\ ${ }^{1}$ Department of Geology, University of Buea, P.O Box 63 Buea, Cameroon \\ ${ }^{2}$ Centre for Geological and Mining Research, P.O Box 333 Garoua, Cameroon \\ *Corresponding author: anabafotze@yahoo.fr
}

Received November 18, 2018; Revised January 08, 2019; Accepted February 09, 2019

\begin{abstract}
A geological based remote sensing study was carried out over the Poli group in Garoua (northern Cameroon), renowned for its hydrothermally occurring mineralizations (Gold and Uranium). In this study, Landsat 8 OLI/TIRS coupled with magnetic data were used in order to realize a regional litho-structural mapping of hydrothermal alteration targets, required for mineral exploration. Hence, the enhancement of both Landsat 8 and magnetic data was achieved via digital image processing (DIP) techniques notably Band rationing (BR), Principal Component Analysis (PCA), Horizontal gradient (HG), and lineament extraction algorithms. Based on reference band ratio combinations (Sultan's and Kaufmann's) and Crosta Technique (PCA analysis), hydrothermally altered minerals such as hydroxyl-bearing minerals and iron oxides were identified. The PCA map was shown to better illustrate hydrothermally altered areas than Band ratios. Thus, a classification map emphasizing on mineral targets was obtained from the PCA map. Besides, the CET grid analysis tool (horizontal gradient) from Geosoft software 8.4 and the line algorithm (pan band 8) from Geomatica 2013 allowed the extraction of subsurface and surface lineaments respectively. The resulting lineaments showed a predominant $\mathrm{E}-\mathrm{W}$ trending direction, which suggests a major tectonic event having prevailed within the area. Other directions include NE-SW/ENE-WSW, and N-S. The generation of a target exploration map, via ArcGIS 10.4.1, was performed by the overlay of hydrothermal alteration mapping and structural mapping. New regional maps, providing a useful insight for further mining exploration, were obtained.
\end{abstract}

Keywords: digital image processing, hydrothermal alteration mapping, landsat 8, magnetic data, Poli group, structural mapping

Cite This Article: Quentin Marc Anaba Fotze, Anatole Eugene Djieto Lordon, Joseph Penaye, Jean Paul Sep, and Mary Immaculate Neh Fru, "Mapping Hydrothermal Alteration Targets from Landsat 8 OLI/TIRS and Magnetic Data Using Digital Image Processing Techniques in Garoua, North Cameroon.” Journal of Geosciences and Geomatics, vol. 7, no. 1 (2019): 28-41. doi: 10.12691/jgg-7-1-4.

\section{Introduction}

Since decades, the advent of accurate Remote Sensing technology has had a great impact on the development of many countries, by improving knowledge and insight on strategic economic domains such as mining and oil exploration, agriculture, water survey, environment, urbanization, and risk management, etc. Indeed, remotely sensed data have the advantage of providing a synoptic overview of very large areas, regardless of fieldwork constraints (limited study area, inaccessibility, climate conditions, natural disasters, political and social instabilities). Therefore, surveys undertaken from Remote Sensing data are less-time/money consuming and they may provide better results than any ground investigation when properly utilized.

Besides, Geological Remote Sensing is considered as an important approach to identify minerals through spectral anomalies enhanced by specific techniques [1,2]. Indeed, Remote Sensing allows the identification of hydrothermal alteration processes, as well as lineaments and other valuable geologic information [3]. Hence, Remote Sensing method appears to be an important tool in the regional exploration of significant mineralizations, especially those resulting from hydrothermal alteration processes.

Two types of Remote Sensing technology have been applied in this work Landsat 8 OLI/TIRS and Airborne Magnetism.

Nowadays, the Magnetic method is considered as one of the most useful available technology that helps in the 
illustration of the surface and subsurface geology. Indeed, based on specific enhancement techniques (Euler Deconvolution, Horizontal and Vertical derivatives), it is possible to map the shallow and deep structural framework of any area. This could help in the identification of eventual ore deposits since they commonly occur along areas of weakness such as faults.

Hence, in a developing country with a great mining potential such as Cameroon, Magnetic data enhancement seems to be an undeniable technology required for the economic improvement of the country.

Former work carried out in Cameroon and specifically within the study area mostly involved Gravity Data Processing. Indeed, [4] and [5] used Gravity data to illustrate the subsurface structural framework and its mining implication in Garoua, Northern Cameroon. Thus, the use of Magnetic data in a view to extracting deep-seated lineaments still remains a great challenge.

The Landsat 8 OLI/TIRS which is the eighth satellite in the Landsat program was launched on 4 February 2013. Therefore, it is the most recent Landsat satellite, equipped with two-sensor payload (Operational Land Imager and the Thermal Infrared Sensor), thereby providing an increased coverage of the Earth's surface.

However, despite the launch of Landsat 8 OLI/TIRS data, more scientific articles involving the enhancement of Landsat 7 ETM+ data are still being published regardless of Landsat 8 OLI/TIRS data which are more recent. Indeed, previous work based on Landsat data utilization in Cameroon include: [6] who used Landsat 7 ETM+ to discriminate geological structures in the Archean basement rocks of Sangmelima, Southern Cameroon; [7] also processed Landsat 7 ETM+ data to enhance the geological structure of Ngoura-Colomines area, Eastern Cameroon; similarly, [8] used Landsat 7 ETM+ to illustrate litho-structural features of the Abiete-Toko gold district in Southern Cameroon.

Hence, no scientific study emphasizing on Landsat 8 OLI/TIRS data processing in Cameroon has been published; their utilization in this study appears to be a great innovation for the country hence. Besides, [9], in a comparative study between Landsat 7 ETM+ and Landsat $8 \mathrm{OLI} / \mathrm{TIRS}$ for mapping geology in the central region of Kenya, showed that Landsat 8 OLI/TIRS performs better than Landsat 7 ETM+ in discriminating rock types.

[10] suggested that the initial occurrence of Gold in Vaimba-Lidi area (locality within the study area) should be caused by volatile emanations related to the granitic emplacement; that process concentrated Gold and sphalerite in country rocks as veins and altered wall-rock halos. Besides, [11] showed that the Uranium concentration in Poli area (Kitongo) was strongly related to hydrothermal alteration. The concentration of uranium at fault intersections rather than along individual faults implies that structural events and hydrothermalism seem to influence the mineralization.

Therefore, considering the hydrothermal alteration process prevailing in the study area, the main objective of this work is to identify potential sites of mineralizations in the area by providing an exploration map. Thus, the achievement of this aim involves the identification of hydrothermal targets and extraction of surface lineaments via Digital image processing (DIP) techniques (spatial and spectral enhancement) of Landsat 8 OLI/TIRS data, coupled with the extraction of subsurface structures from Airborne Magnetic data processing.

\section{Geological and mining setting}

The Central African Fold Belt was formed by the collision between Congo, West African and East Sahara cratons during the Pan-African orogeny [12]. It includes three structural groups separated by major shear zones: (1) Southern Supergroup, (2) the Central Supergroup and (3) the Northern Supergroup. The study area (Figure 1) is located in Garoua, Northern Cameroon. It belongs to the Northern Supergroup of the CAFB which is divided into two main domains: the North Western (NW) Cameroon and Adamawa-Yadé domains [13], separated from each other by the sinistral Tcholliré shear zone (TSZ) trending NE-SW.

At the western side of TSZ, in the NW Cameroon domain, appears the Poli Group. This group, set up between 700 and $665 \mathrm{Ma}$ [14], corresponds to an early back-arc orogenic basin [15]. The Poli group is dominated by metavolcanic and metasedimentary formations [16]. The metavolcanic unit includes sodic rhyolites and tholeiitic basalts although the metasedimentary unit is formed of volcanogenic clastic rocks like tuffs or variably reworked clastic rocks of dominantly intermediate composition like metagreywackes [17]. Albitized granite of Kitongo (around Poli) host Uranium mineralization including interleaved sequences of metasedimentary and metavolcanic rocks [11]. According to [11], the Uranium mineralization of Kitongo is related to $\mathrm{Na}-\mathrm{Ca}$ metasomatism associated with brittle faults cross-cutting ENE trending ductile shear zones. Apart from Uranium, the Poli Group is enriched in gold associated with Copper and Silver [18].

Moreover, The NW Cameroon domain includes the Yola-Garoua branch of Benue Trough which is interpreted as the result of the Atlantic opening during Cretaceous [5]. This Benue branch is described as a graben which is surrounded by minor intracontinental basins (BabouriFiguil, Mayo Rey, Hamakoussou, Mayo Oulo-Léré). The Benue basin consists mainly of Cretaceous sandstones distinguished as «Garoua sandstone» and «Benue sandstone» $[19,20]$ associated with volcanism and plutonic intrusions.

At the southeastern of the Benue Trough, it crops out batholiths of Sinassi associated with the Rey Bouba greenstones. Those greenstones are related to Tcholliré Shear zone and made up mainly of greenschist-facies mafic to felsic volcanic, volcano-sedimentary and sedimentary rocks associated with a set of pre-, syn- and post-tectonic granitoids, and dykes.

The study area is located in Poli group which hosts considerable mineralizations notably Uranium (Poli, Batandje) and Gold (Bibémi, Tchollire). An intense activity of gold mining is observed in Vaimba-Lidi drainage system (Eastern side of Rey Bouba) where the concentration may reach $1.12 \mathrm{~g} / \mathrm{t}$ [10] or above $2.79 \mathrm{~g} / \mathrm{t}$ [21]. According to [21], gold mineralizations are located on late fractured zones. [10] suggested that granitic batholiths should be the primary source of gold mineralizations. Furthermore, Gold indexes have been found on granitoids and gneisses of Bandioukri area [18]. However, mineral exploration processes are still ongoing within the study area. 

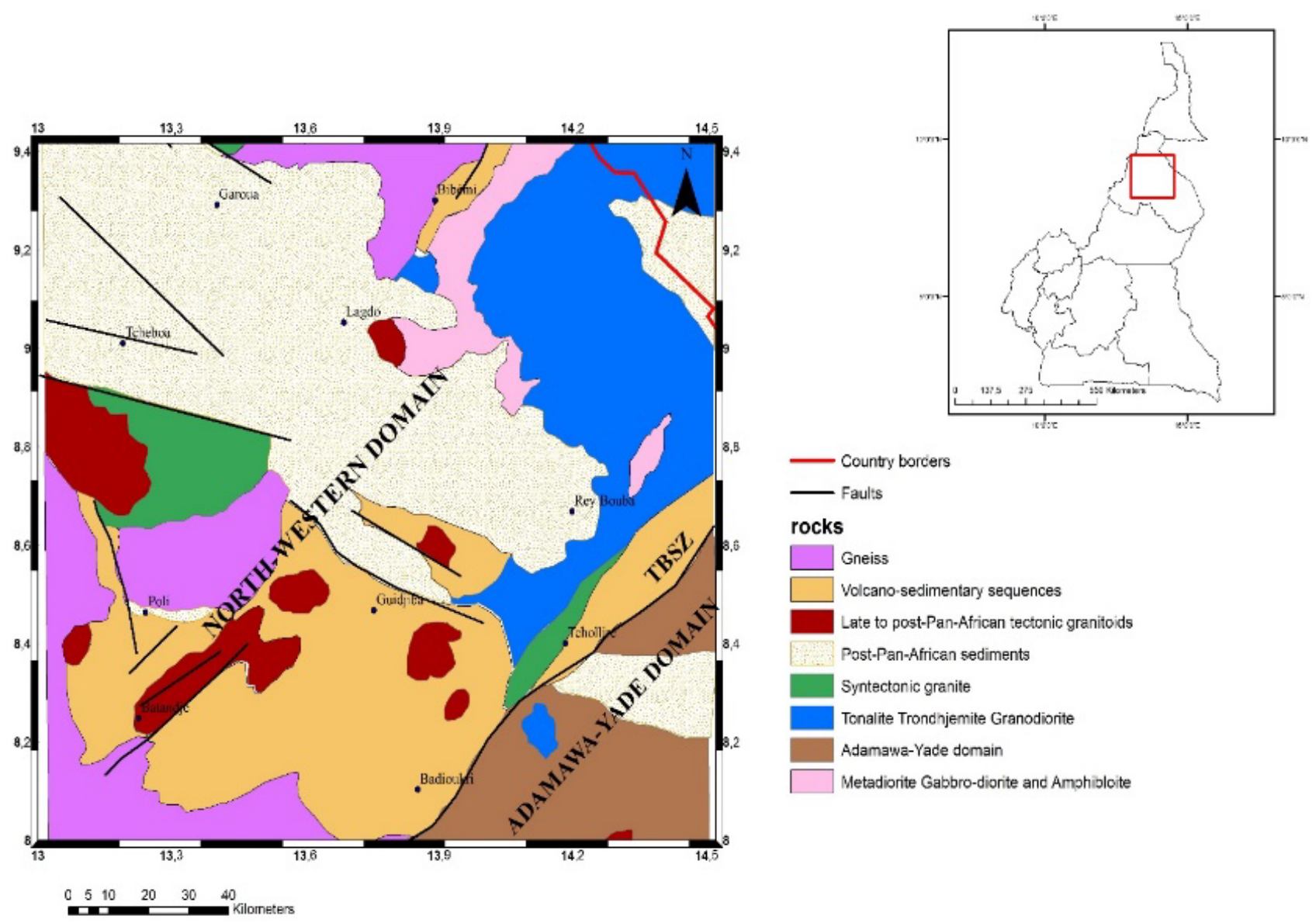

Figure 1. Location and geological maps of the study area (red square), modified from [14]

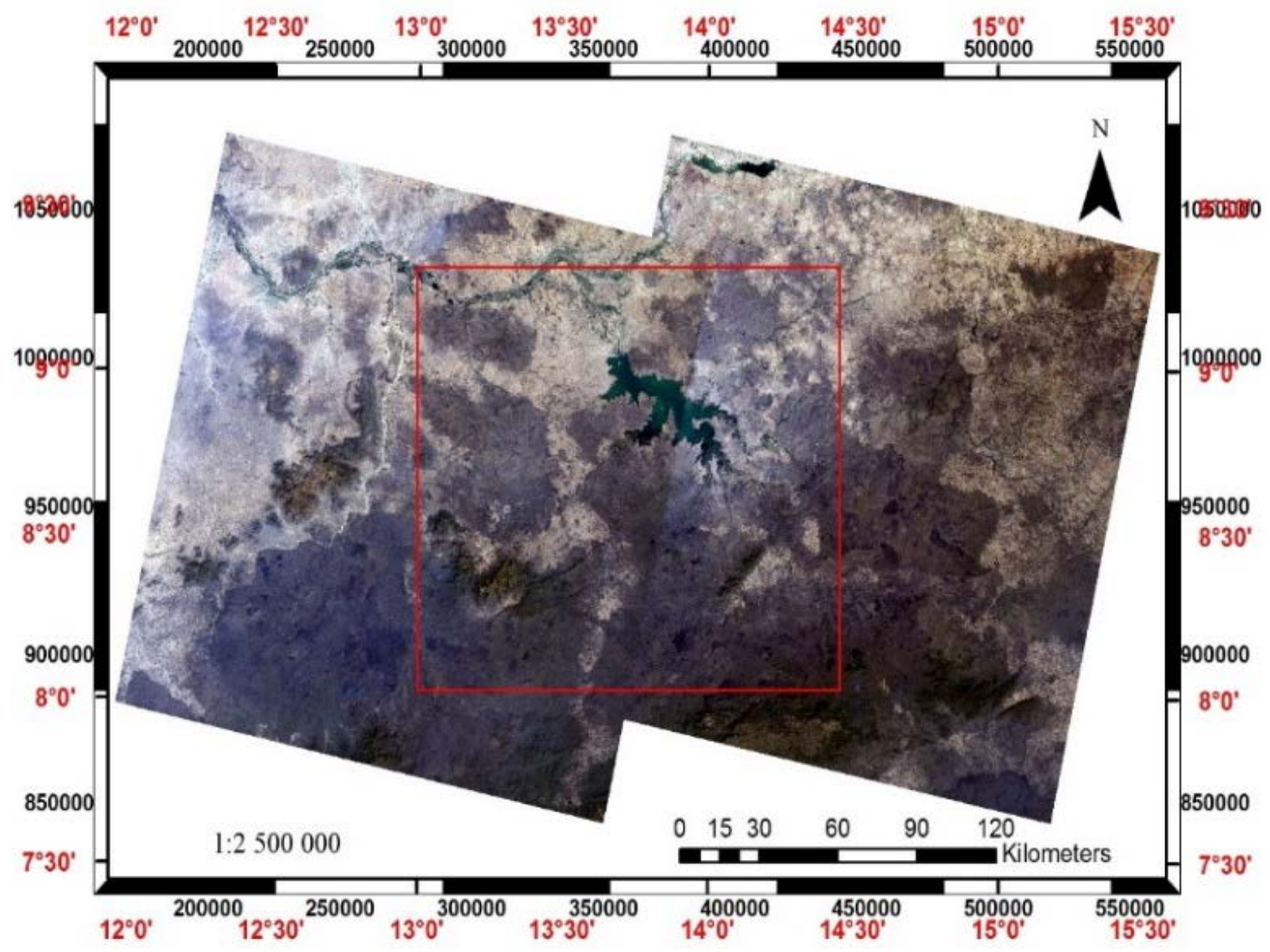

Figure 2. Mosaicked Landsat 8 OLI/TIRS scenes (true color) covering the study area (red square) 


\section{Materials and Methodology}

\subsection{Materials}

Cloud-free Landsat 8 OLI scenes were obtained from the U.S Geological Survey website. The period of acquisition was January 2018 which corresponds to the dry season, improving the visibility of Landsat sensors. A total of 2 OLI scenes covering the study area have been utilized in this work (Figure 2). The data were georeferenced to Universal Transverse Mercator (UTM), World Geodetic system 1984 (WGS 84) zone 33N.

Landsat-8 Operational Land Imager (OLI) images consist of 11 spectral bands whose characteristics are shown in Table 1.

Table 1. Landsat 8 sensors characteristics

\begin{tabular}{|c|l|c|c|}
\hline Bands & Band name & $\begin{array}{c}\text { Wavelength } \\
\text { (micrometers) }\end{array}$ & Resolution \\
\hline 1 & Coastal aerosol & $0.433-0.453$ & 30 \\
\hline 2 & Blue & $0.450-0.515$ & 30 \\
\hline 3 & Green & $0.525-0.600$ & 30 \\
\hline 4 & Red & $0.630-0.680$ & 30 \\
\hline 5 & Near Infrared (NIR) & $0.845-0885$ & 30 \\
\hline 6 & Short Wave Infrared (SWIR) 1 & $1.560-1.660$ & 30 \\
\hline 7 & Short Wave Infrared (SWIR) 2 & $2.100-2.300$ & 30 \\
\hline 8 & Panchromatic & $0.500-0.680$ & 15 \\
\hline 9 & Cirrus & $1.360-1.390$ & 30 \\
\hline 10 & Thermal Infrared (TIRS) 1 & $10.6-11.2$ & 100 \\
\hline 11 & Thermal Infrared (TIRS) 2 & $11.5-12.5$ & 100 \\
\hline
\end{tabular}

Landsat 8 Images were digitally processed and analyzed using ENVI 5.1, ILWIS 3.3, ArcGIS 10.4.1, PCI Geomatica 2013 and Rockworks 16.
Moreover, Airborne Magnetic data used in this study were extracted from a global Earth Magnetic Anomaly Grid commonly known as EMAG2. EMAG2 is a dataset of satellite, ship and airborne magnetic measurements merged to an altitude of $4 \mathrm{~km}$ with a resolution of 2 arcmins [22].

The processing of magnetic data was performed using Geosoft 8.4 version.

\subsection{Methodology}

The data processing and subsequent image enhancements are summarized in the methodology flow chart (Figure 3) below.

Ilwis was used to calculate the OIF (Optimum Index Factor) in order to determine the suitable band combination with the least redundancy and highest feature identification. The number of possible RGB color composites of $\mathrm{N}$ bands $=(\mathrm{N}$ !) / (3 !*(N-3)!). In Landsat 8 bands, we use $\mathrm{N}=7$, which gives 35 possible color composites. The highest informative band combinations are shown in Table 2.

Table 2. Optimum Index Factor statitics of Landsat 8 bands

\begin{tabular}{|c|c|c|c|}
\hline \multicolumn{4}{|c|}{ OIF Index Highest Ranking } \\
\hline band 1 & band 5 & band 6 & $\mathbf{( 9 7 . 8 8 )}$ \\
\hline band 1 & band 5 & band 7 & $\mathbf{( 9 6 . 5 3 )}$ \\
\hline band 1 & band 4 & band 5 & $(95.66)$ \\
\hline band 2 & band 5 & band 6 & $(95.60)$ \\
\hline band 5 & band 6 & band 7 & $(94.92)$ \\
\hline band 1 & band 4 & band 6 & $\mathbf{( 9 4 . 8 8 )}$ \\
\hline
\end{tabular}

Therefore, the most accurate RGB color composite band combination is 6, 5, 1 (Figure 4). The resultant false color composite is displayed below.

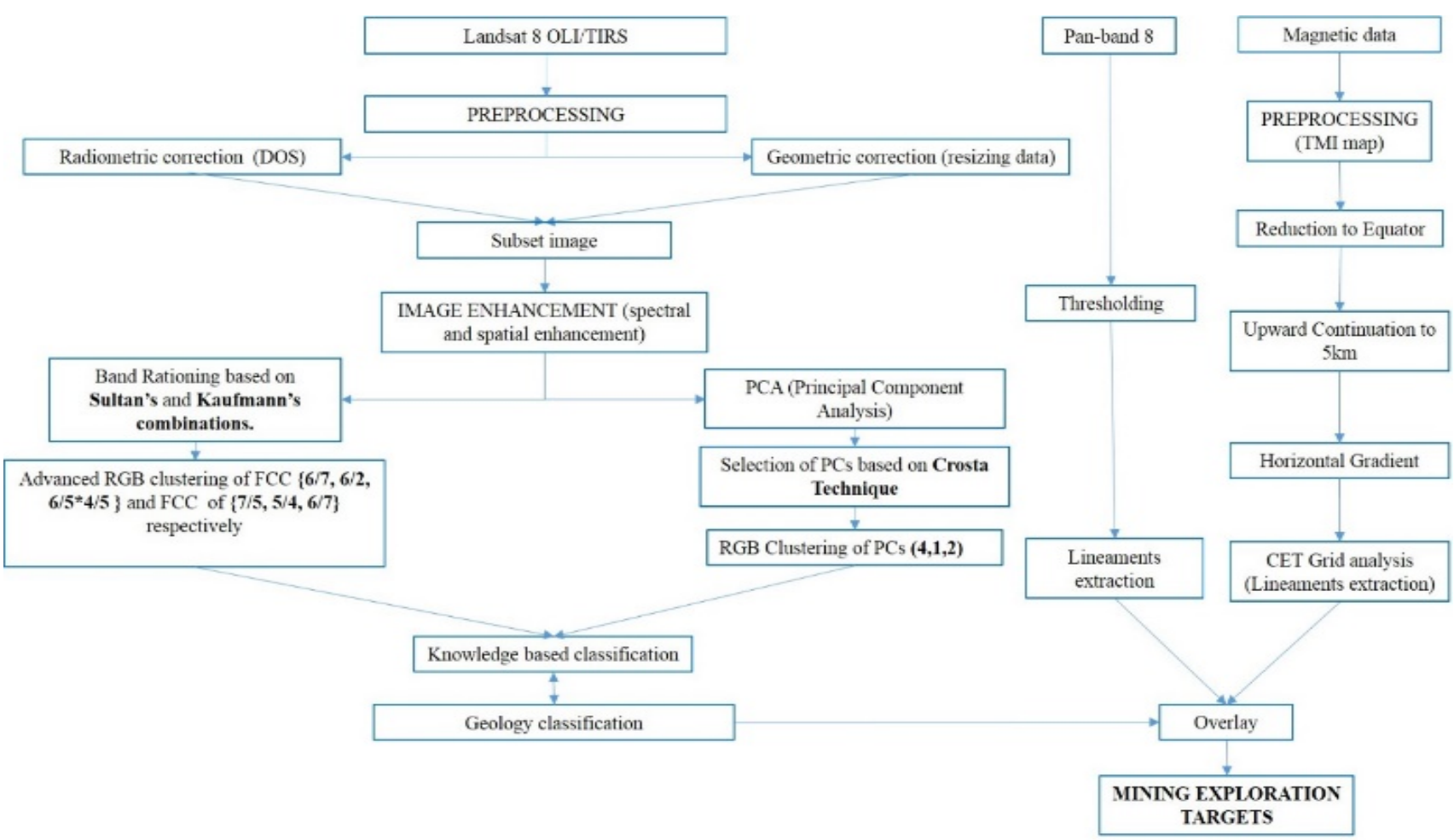

Figure 3. Summary of the methodology Flow chart using Landsat 8 OLI/TIRS and Magnetic data 


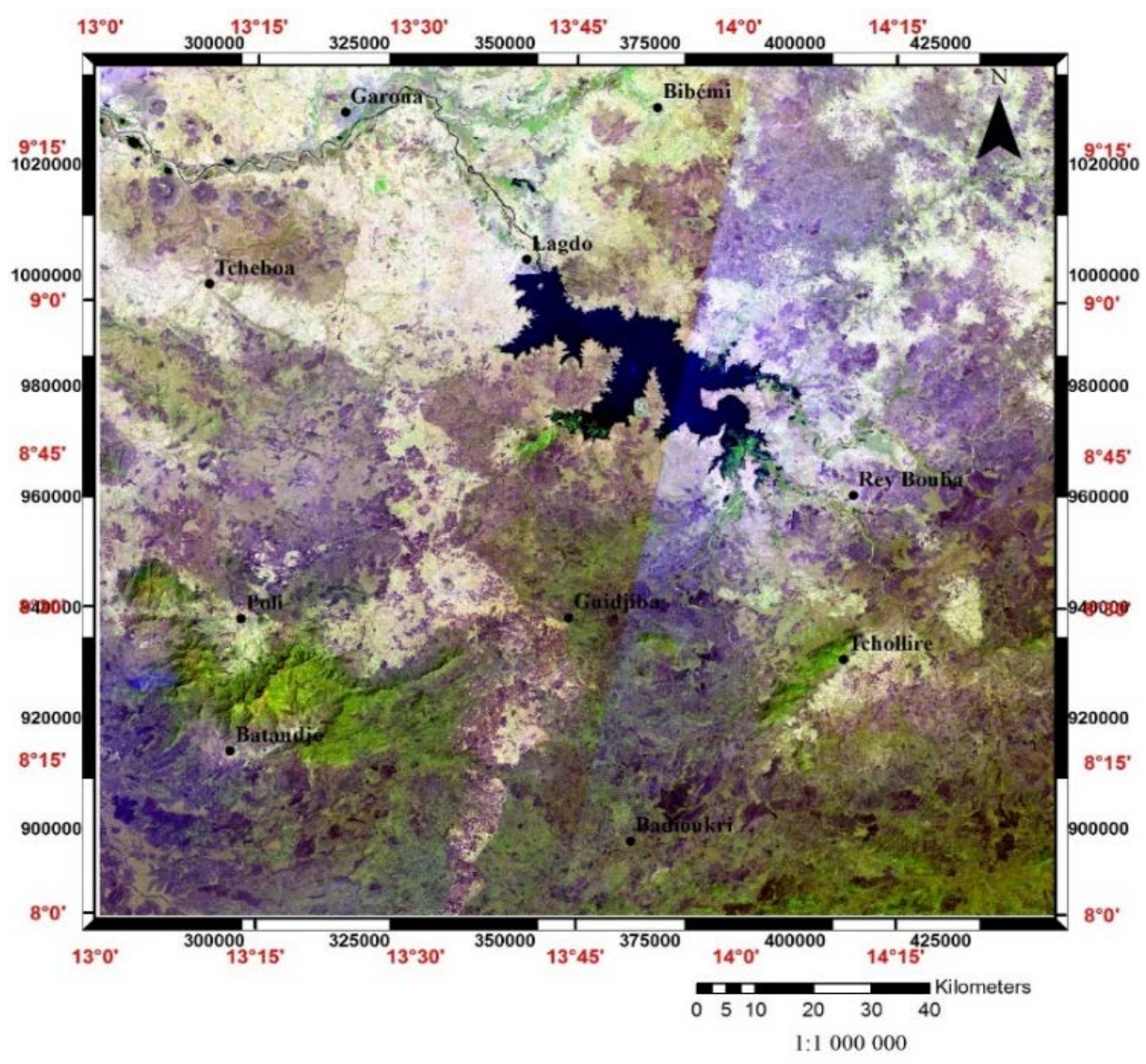

Figure 4. Preprocessed FCC of 6,5,1 in RGB

The different processing algorithms performed in this study are explained below.

\subsubsection{Band Rationing (BR)}

It is a multispectral image processing technique that implies dividing the digital numbers of one band by their corresponding pixels in another band. This algorithm is commonly used to enhance spectral differences between land surface materials. Hence, band rationing allows discrimination between several rock types and may be used to highlight areas rich in specific mineral compositions based on reference band ratio combinations [1,2,3,23]. Indeed, previous studies undertaken in arid areas showed that band ratio combinations suitable for geologic mapping imply Sultan's [24] and Kaufmann's. Besides, these band ratio combinations are commonly used to illustrate hydrothermal alteration targets, key indices of potential mineral resources. Thus, Sultan's and Kaufmann's band ratio combinations in RGB (5/7, 5/1, 5/4*3/4 and 7/4, 4/3, 5/7 in Landsat TM equivalent to 6/7, 6/2, 6/5*4/5 and 7/5, $5 / 4,6 / 7$ respectively in Landsat 8 ) were applied in this study.

\subsubsection{Principal Component Analysis (PCA)}

It is a spectral unmixing technique which transforms multispectral data into their principal components [25]. It highlights similarities and differences, thus allowing us to shrink redundancy in the data. The output shows the eigenvalues and eigenvectors of the covariance matrix to be interpreted. This interpretation was carried out based on the Crosta technique [26], where the Eigenvector statistics output of PCA was analyzed in a view to identifying the PC holding the spectral information of the target minerals.

Later on, an unsupervised classification was used for classifying hydrothermal targets enhanced by Principal Component Analysis. This classification was achieved using Envi 5.1 and ArcGIS 10.4.1.

The ENVI software was principally used for the preprocessing and processing steps of Landsat 8 images.

\subsubsection{Lineaments/Structures Extraction}

Lineaments are rectilinear features resulting from fracturing/faulting or structurally controlled topographic lines. They may reflect subsurface phenomena [27], when 
controlled by geological structures (joints, fractures, and faults). The importance of lineaments related to geological structures is of great importance since they act as a reservoir for oil, water and ore deposits.

In this work, lineaments extraction was performed based on both Landsat 8 (pan band 8) and magnetic data.

\section{- Lineaments extraction via pan band 8}

Geomatica 2013 was used to automatically extracting surface lineaments from the highest resolution band 8 (panchromatic). ArcGIS 10.4.1 helped us to analyze statistically lineaments and to provide suitable format (Autocad) for their use in Rockworks 16, designed for rose diagram performance.

\section{- Structures extraction via magnetic data}

Magnetic data were used and processed in order to identify major buried structures which could have a significant economic importance according to the mining potential of the area. This approach is complementary to surface lineaments extraction achieved from Landsat 8 data. The processing techniques applied using Oasis Montaj 8.4 (Geosoft) are detailed below.

\section{(i) Reduction-to-Equator (RTE)}

Reduction to the Equator is an operator commonly used to remove magnetic inclination in low magnetic latitudes and center the peaks of magnetic anomalies over their sources. This algorithm was applied to the Total magnetic intensity grid (Figure 5a). An inclination and declination of -4.46 and -4.32 respectively were used to achieve Reduction to the Equator of the magnetic field intensity data (Figure 5b) over the study area.
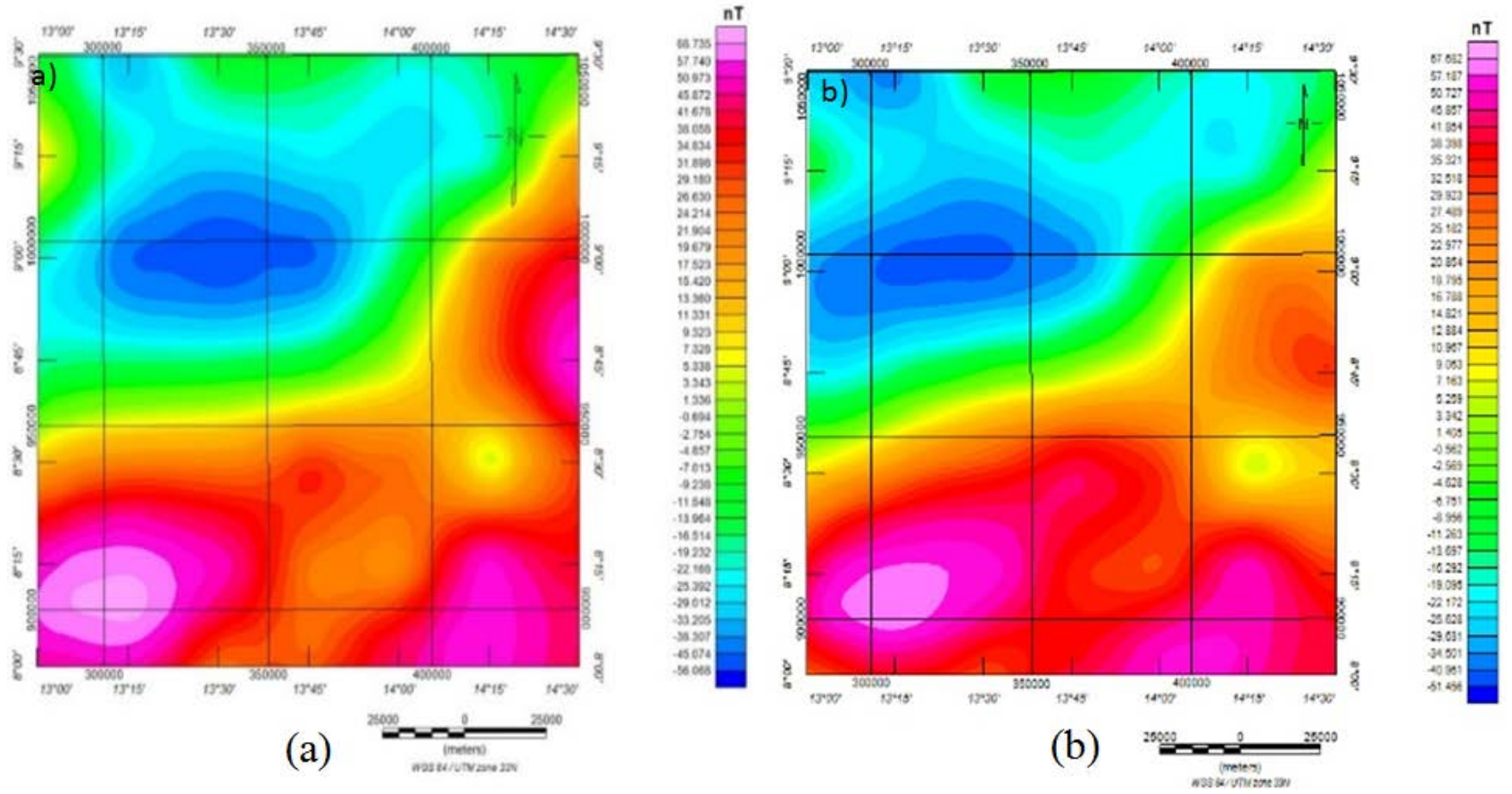

Figure 5. (a) Total Magnetic Intensity, (b) Reduction to-the-Equator (RTE) maps

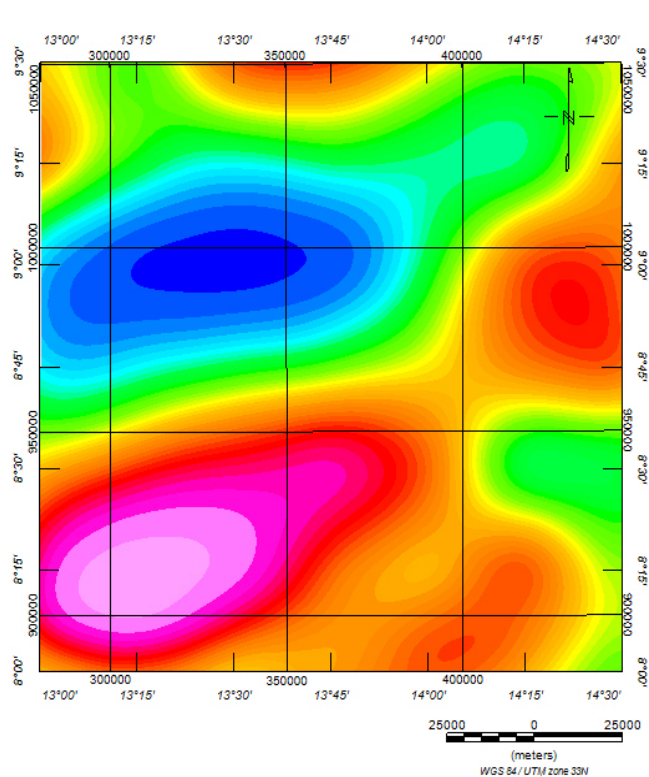

Figure 6. RTE upward continued to $5 \mathrm{~km}$
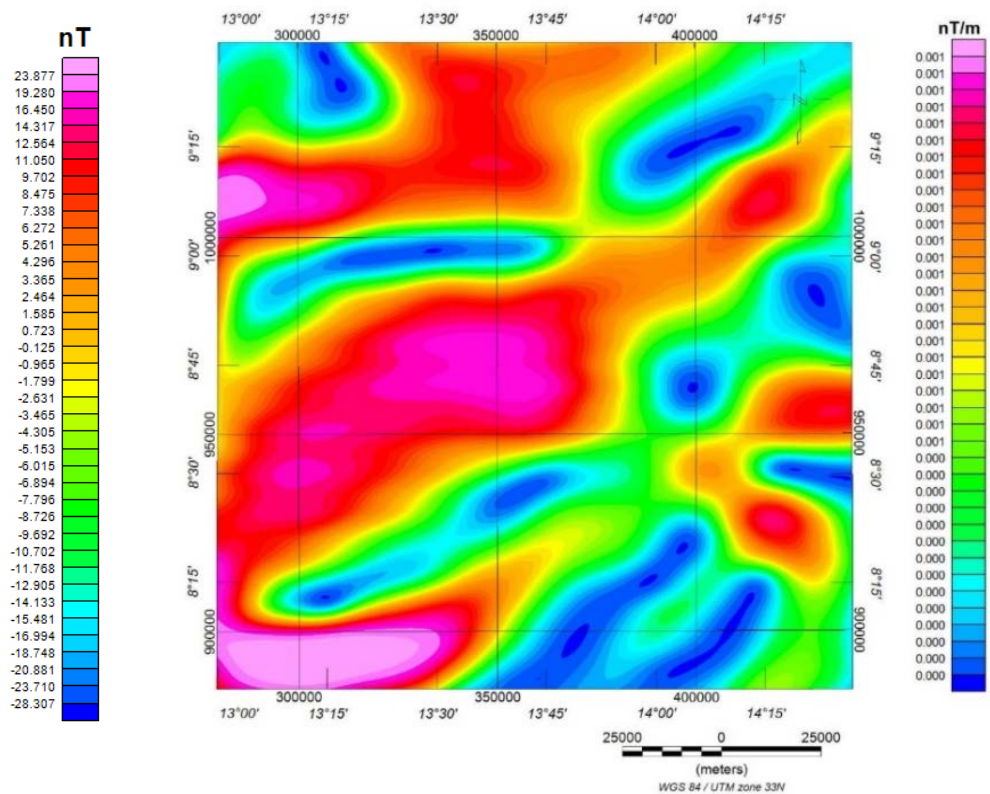

Figure 7. Horizontal gradient of the study area 


\section{(ii) Upward Continuation}

It is a low pass filter whose task is to enhance long wavelength effects (deep sources) at the expense of short wavelengths related to shallow sources or noise. It allows projecting potential field data taken at an elevation to a higher elevation. The effect is that short wavelength features are smoothed out since they are moved away from the anomaly.

Prior to the Horizontal Gradient method, the ReductionTo-the-Equator grid was upward continued to $5 \mathrm{~km}$ (Figure 6) in order to attenuate the short wavenumber noise and smooth the horizontal derivative anomaly grid.

\section{(iii) Horizontal Gradient}

The horizontal gradient method is the simplest approach to estimate contact locations of the bodies at depths. The biggest advantage of the horizontal gradient method relies on its low sensitivity to the noise in the data because it only requires calculations of the two first-order horizontal derivatives of the field [28]. Considering $M$ as the magnetic field, the horizontal gradient formulae (HGM) is given by:

$$
\operatorname{HGM}(x, y)=\sqrt{\left(\frac{\delta M}{\delta x}\right)^{2}+\left(\frac{\delta M}{\delta y}\right)^{2}} .
$$

In this study, we obtained the horizontal gradient map (Figure 7 ) from the horizontal derivatives ( $d x$ and $d y$ ) by applying the above formulae in grid math.

\section{Results and Discussion}

\subsection{Band Ratio Analysis}

In addition to reference band ratios and individual grayscale, high-resolution views from Google Earth Pro were used to providing a suitable identification of features and distinction between those having approximately the same DN value. Indeed, band ratio 6/7, commonly used to enhance hydroxyl-bearing minerals, was found to display the vegetation cover as well, obstructing the pertinence of the results. Hence, we subtracted the vegetation cover (5/4 band ratio) from $6 / 7$ band ratio prior to false color band ratio combinations.

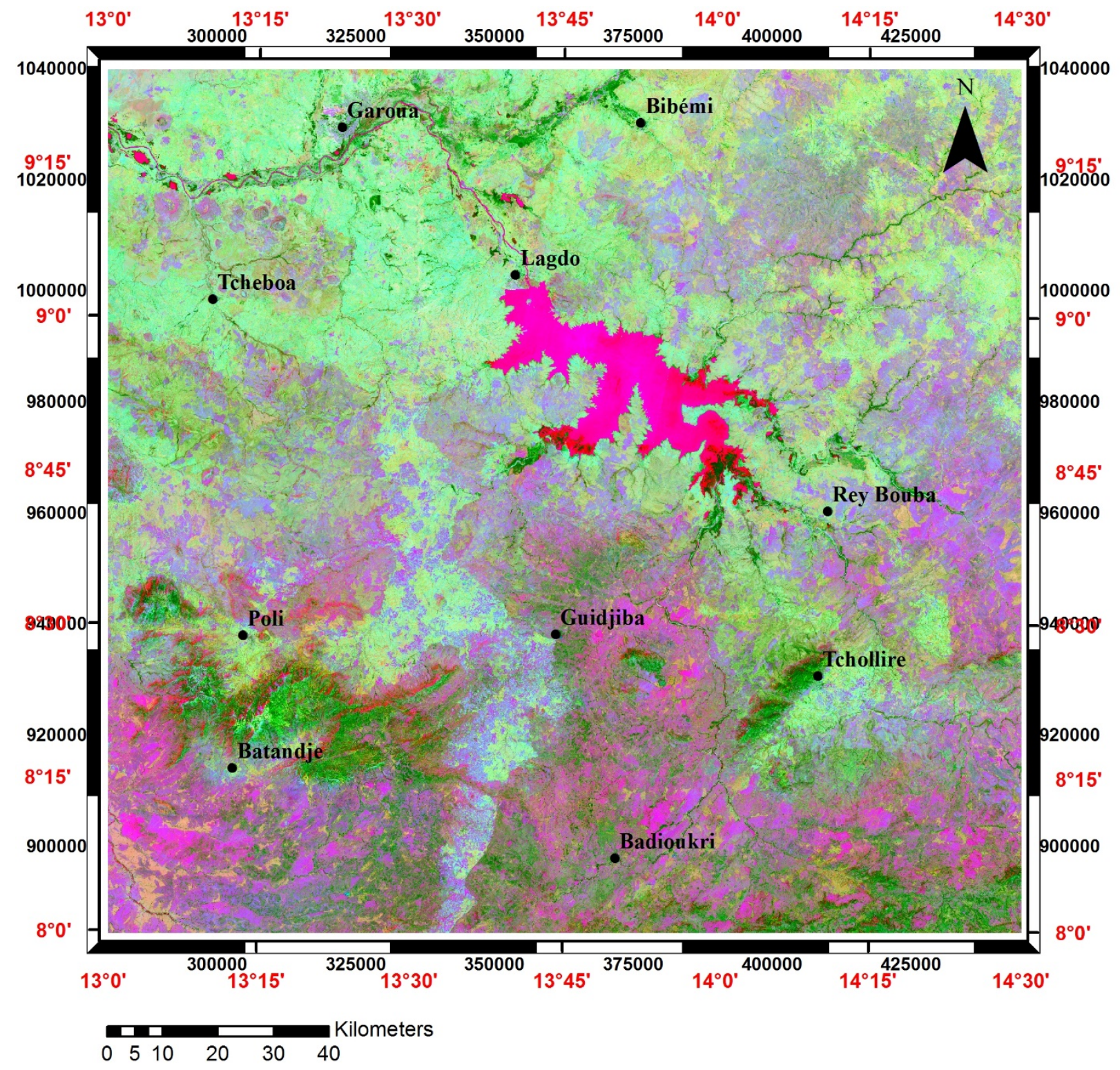

Figure 8. Landsat 8 band ratio 6/7, 6/2, 6/5*4/5 in RGB [2] of the study area 


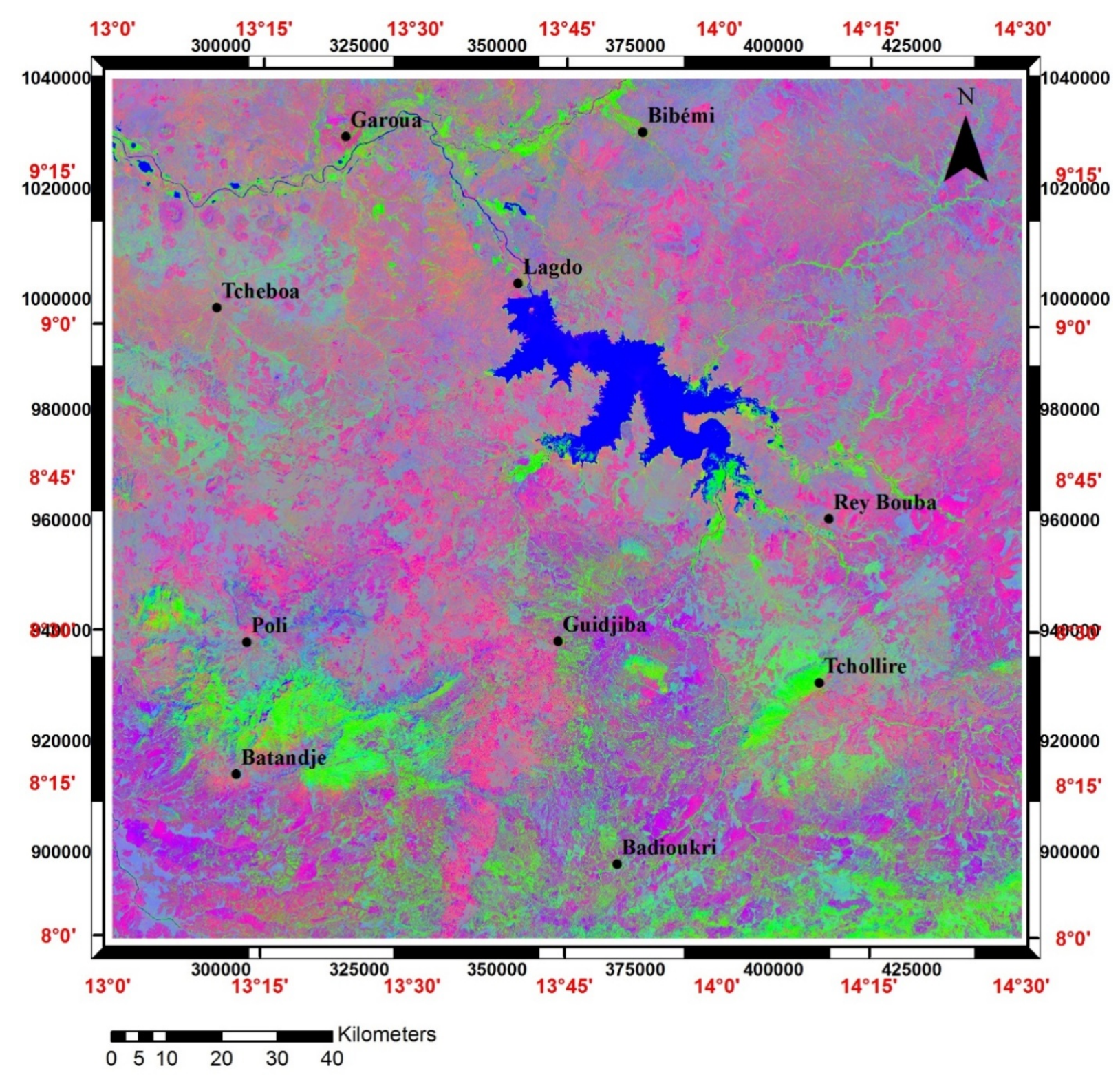

Figure 9. Landsat 8 band ratio 7/5, 5/4, 6/7 in RGB [1] of the study area

The results of Sultan's band ratio combinations 6/7, 6/2, $6 / 5 * 4 / 5$ in RGB (Figure 8) allow the discrimination of several features. Vegetated areas and water appear as dark green and dark pink colors respectively. Brown (coffee milk) color, hardly discernible, enhances hydroxyl-bearing minerals (clay minerals, mica, talc-carbonate). These minerals, characterized by high reflectance in band 6 and deep absorption properties in band 7 [2], are typical indicators of hydrothermal alteration; magnetite occurrence (6/2) is illustrated in turquoise (bluish green) whereas iron oxides and iron-bearing minerals $(6 / 5 * 4 / 5)$, mostly concentrated in the southern side of the study area, are highlighted in light purple and pinkish colors.

Likewise, Kaufmann's band ratio combinations 7/5, 5/4, 6/7 in RGB (Figure 9) illustrate vegetation zones in green (ratio 5/4), while water (drainage pattern) is represented in dark blue. Ferric and ferrous iron depicted by band 7/5 are expressed in pink color. Med blue seems to highlight altered areas rich in hydroxyl-bearing minerals (6/7) which are strongly obvious in this band ratio combination. It shows that Kaufmann's ratio enhances hydroxyl-bearing minerals better than Sultan's ratio in this study.

\subsection{PCA Analysis}

Using statistics below (Table 3), it is noticed that band 6 contributes more than the other bands. Besides, PC1 represents $94.33 \%$ of the total variance. PC1, PC2 and PC4 were selected based on their eventual geologic information. Indeed, PC1 shows a contrast between band 6 $(0,67)$ and band $2(0,08)$; PC2 expresses a high difference between band $7(0,67)$ and band $5(-0,75)$ whereas PC4 highlights a contrast between band $6(-0,64)$ and band 7 $(0,56)$. However, an inverse of PC4 was created in order to enhance the effect of hydroxyl-bearing minerals (6/7).

Displaying PC4 inverted, PC1, and PC2 in RGB (Figure 10) illustrates altered zones dominated by hydroxyl-bearing minerals in orange. Purple and blue enhance the signature of ferric and ferrous minerals. Magnetite occurrence is marked as turquoise and light green colors. Vegetation and water are displayed in dark green and pink respectively. 
Table 3. Eigenvectors and eigenvalues of PCA on Landsat 8 imagery

\begin{tabular}{|c|c|c|c|c|c|c|c|c|}
\hline Eigenvector & Band 1 & Band 2 & Band 3 & Band 4 & Band 5 & Band 6 & Band 7 & Eigenvalue\% \\
\hline Stdev & 0,009 & 0,012 & 0,020 & 0,035 & 0,065 & 0,088 & 0,065 & 94,33 \\
\hline PC 1 & 0,06 & 0,08 & 0,14 & 0,26 & 0,47 & 0,67 & 0,48 & 4,19 \\
\hline PC 2 & 0,07 & 0,07 & 0,03 & 0,04 & $-0,74$ & 0,01 & 0,67 & 0,94 \\
\hline PC 3 & 0,24 & 0,34 & 0,53 & 0,64 & 0,01 & $-0,36$ & $-0,10$ & 0,42 \\
\hline PC 4 & $-0,06$ & $-0,08$ & $-0,05$ & $-0,17$ & 0,48 & $-0,64$ & 0,56 & 0,10 \\
\hline PC 5 & $-0,61$ & $-0,47$ & $-0,19$ & 0,60 & $-0,06$ & $-0,05$ & 0,02 & 0,02 \\
\hline PC 6 & 0,45 & 0,19 & $-0,80$ & 0,35 & 0,05 & $-0,06$ & 0,00 & 0,00 \\
\hline PC 7 & $-0,60$ & 0,78 & $-0,17$ & $-0,05$ & 0,01 & 0,00 & 0,00 & \\
\hline
\end{tabular}

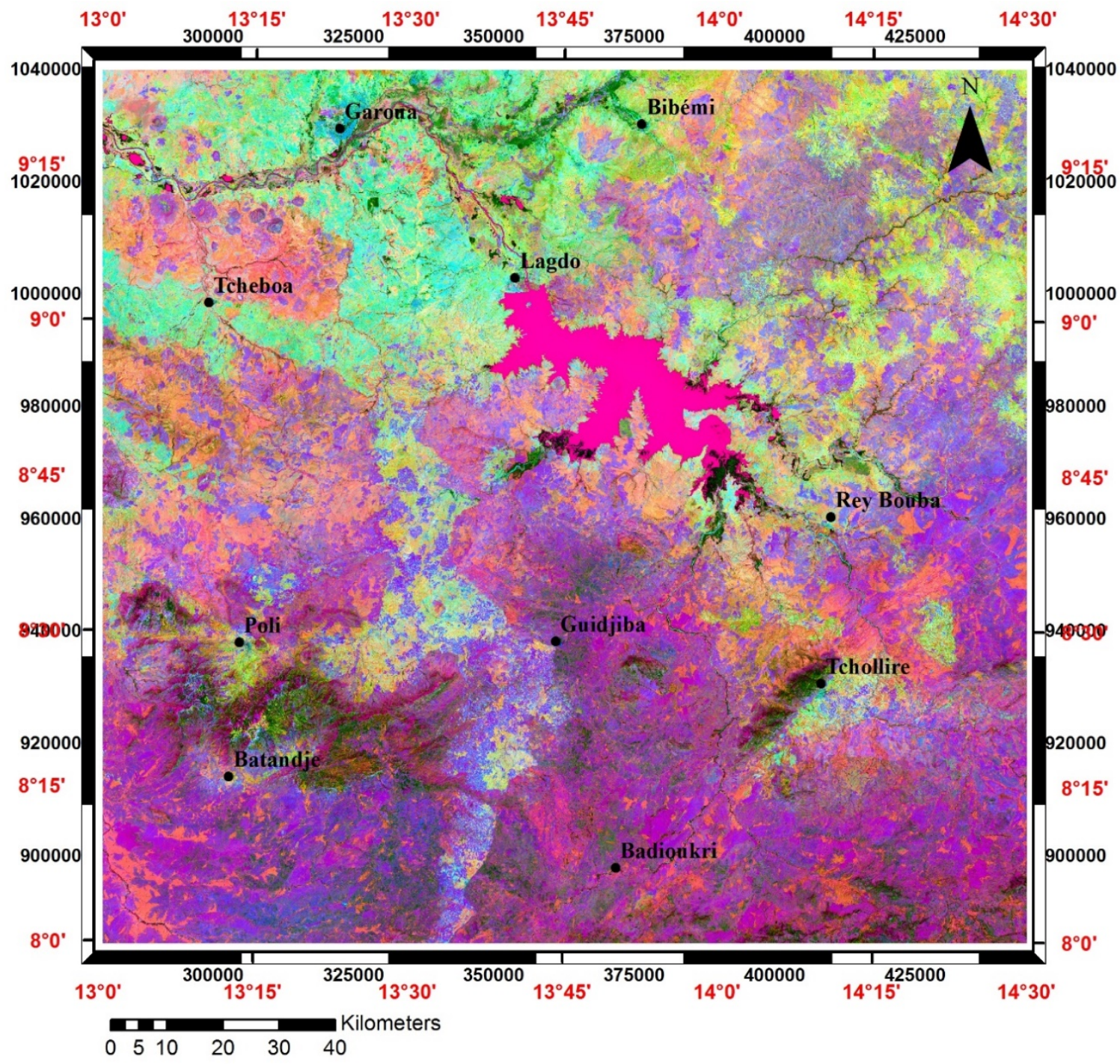

Figure 10. False color composite of PC4 (inverted), PC1, and PC2 in RGB

PCA map (Figure 10) enhances more features and better results than Band rationing (Figure 8). Hence, the PCA map was selected to achieve an unsupervised classification. Thus, a hydrothermal alteration map (Figure 11), illustrating the potential targets of mineral exploration within the study area, was obtained. Besides, Gold indices $[18,29]$, and Uranium prospects [11] were superimposed on this map in order to correlate results with known mineral prospects.

Thus, we can observe from the hydrothermal alteration map that Ferric and ferrous minerals (in red color) cover the southern side of the area while Hydroxyl-bearing minerals (in purple color), well-spread all over the area, are mostly found in the northern side. This discontinuity was confirmed from Figure $5 a$ and Figure 5b, where high magnetic anomalies are concentrated in the South and low magnetic anomalies are mostly detected in the North. Moreover, a positive correlation between predictive targets and known Gold/Uranium indices is discernible, especially in areas where both Ferric/Ferrous minerals and Hydroxyl-bearing minerals are observed. However, other known "golden " province such as Bibémi, appears to be mostly related to Hydroxyl-bearing minerals. 


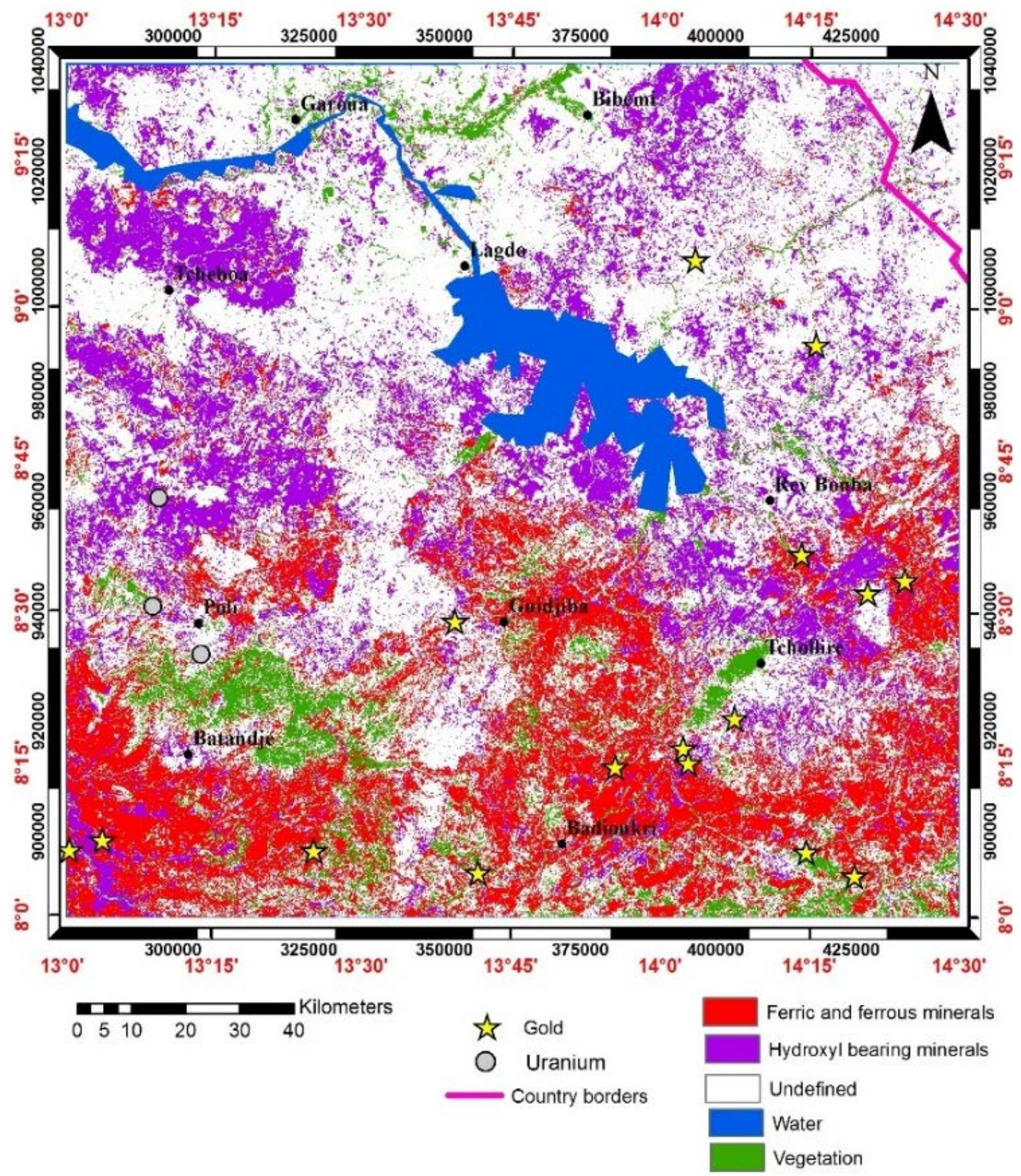

Figure 11. Geological classification of the study area showing hydrothermally altered areas

\subsection{Lineament Analysis}

\subsubsection{Via Landsat 8 Data}

Due to its high spatial resolution, the panchromatic band 8 was used to extracting lineaments via Geomatica 2013. The parameters used in thresholding are summarized in Table 4. Besides, lineaments related to roads or image boundaries were manually removed. The resulting map (Figure 12a) shows diverse trending directions. The E-W, N-S and ENE-WSW/NE-SW lineaments appear to be the major ones affecting the study area; E-W direction, being the predominant one.

Besides, the line density map (Figure 12b) shows the frequency of lineaments per unit area. Thus, we observe that areas with high lineaments density are Tchollire, Poli,
Batandje, Rey Bouba and Lagdo and Garoua. However, the lineaments occurring in Lagdo and Garoua are mostly related to the water system.

Table 4. Suggested parameters values

\begin{tabular}{|l|c|}
\hline Parameters & Suggested values \\
\hline Filter radius (RADI) & 50 \\
\hline Gradient threshold (GTHR) & 30 \\
\hline Length threshold (LTHR) & 3 \\
\hline Line fitting error threshold (FTHR) & 30 \\
\hline Angular difference threshold (ATHR) & 20 \\
\hline Linking distance threshold (DTHR) & 30 \\
\hline
\end{tabular}



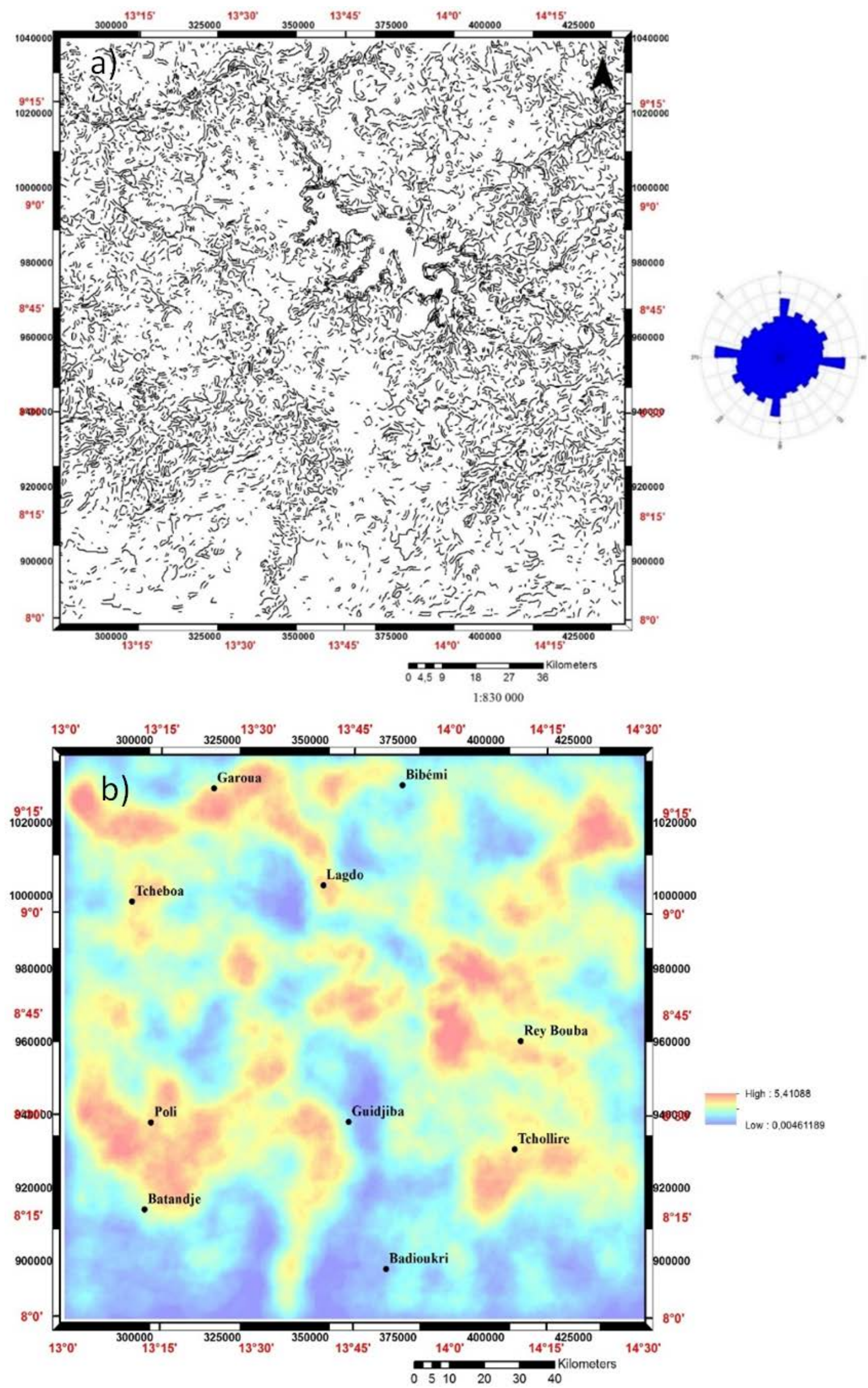

Figure 12. (a) Surface lineaments of the area and (b) Lineaments density maps 


\subsubsection{Via Magnetic Data}

The horizontal gradient grid (Figure 7) was used to extracting lineaments via CET Grid Analysis logarithm in Oasis Montaj 8.4. In order to achieve this 4-step process, we used a congruency robustness of 1 and an amplitude thresholding of $0.0001 \mathrm{nT} / \mathrm{m}$, before performing line thinning (skeletonization) and vectorization. This allowed the obtention of the structural map (Figure 13) of the area.

The rose diagrams show that the area is affected by E-W and NE-SW trending sructures. E-W structures are predominant both in length and frequency.

The study area shows a predominance of both surface (Figure 12) and subsurface (Figure 13) E-W trending direction; this shows that the area must have been affected by a major tectonic event. Besides, the fault trending from Badioukri to Tchollire localities correlates well with the renowned Tchollire Shear zone (TSZ) separating the Adamawa-Yadé domain in the east from the North Western Cameroon domain in the west [13]. Moreover, The TSZ is well-known for hosting Gold-bearing minerals notably in Gamba, Tcholliré, Mayo Rey, Landou, and Poyémé, Mbé localities [29]. Hence, the structures discriminated based on the amplitude thresholding $(0.0001 \mathrm{nT} / \mathrm{m})$ could be of significant economic importance.

\subsection{Litho-structural Map Analysis}

The map below (Figure 14) resulted from the superimposition of surface/subsurface structures and hydrothermally altered minerals. The surface lineaments extracted from the Landsat image (Band 8) were not overlaid on the map for esthetic considerations. Figure 14 this illustrates the correlation between deep/shallow structures and hydrothermally altered rocks.

Considering the mining setting of the study area where noticeable Uranium and Gold deposits have been detected, this final map defines new exploration targets with high probability of mineralization occurrence.

\section{Conclusion}

The processing of Landsat 8 OLI/TIRs and magnetic data allowed us to map the potential targets of mineralizations in the area. Indeed, band rationing, Principal Component analysis and lineaments extraction techniques showed pertinent results in the discrimination of geological features. Thus, the occurrence of hydrothermally altered rocks or minerals (iron oxides, hydroxyl-bearing, clays) has been noticed, as well as several lineaments which may control mineralizations. Besides, high-density lineaments are highlighted in Batandje, Poli, Rey Bouba, Tchollire, and Tcheboa. The E-W trend appears to be predominant in both surface and subsurface, which suggests that the area must have been affected by a major tectonic event.

The economic context of the study area is illustrated by known regions potentially rich in Gold (Bibémi area) and Uranium deposits (Poli and Batandje areas) which may be formed from hydrothermal processes. Indeed, these areas where occurred hydrothermal alteration may be indicating vein deposits. Therefore, the potential map obtained from this study may be a great tool in the exploration and identification of unknown mineral provinces occurring within the area.

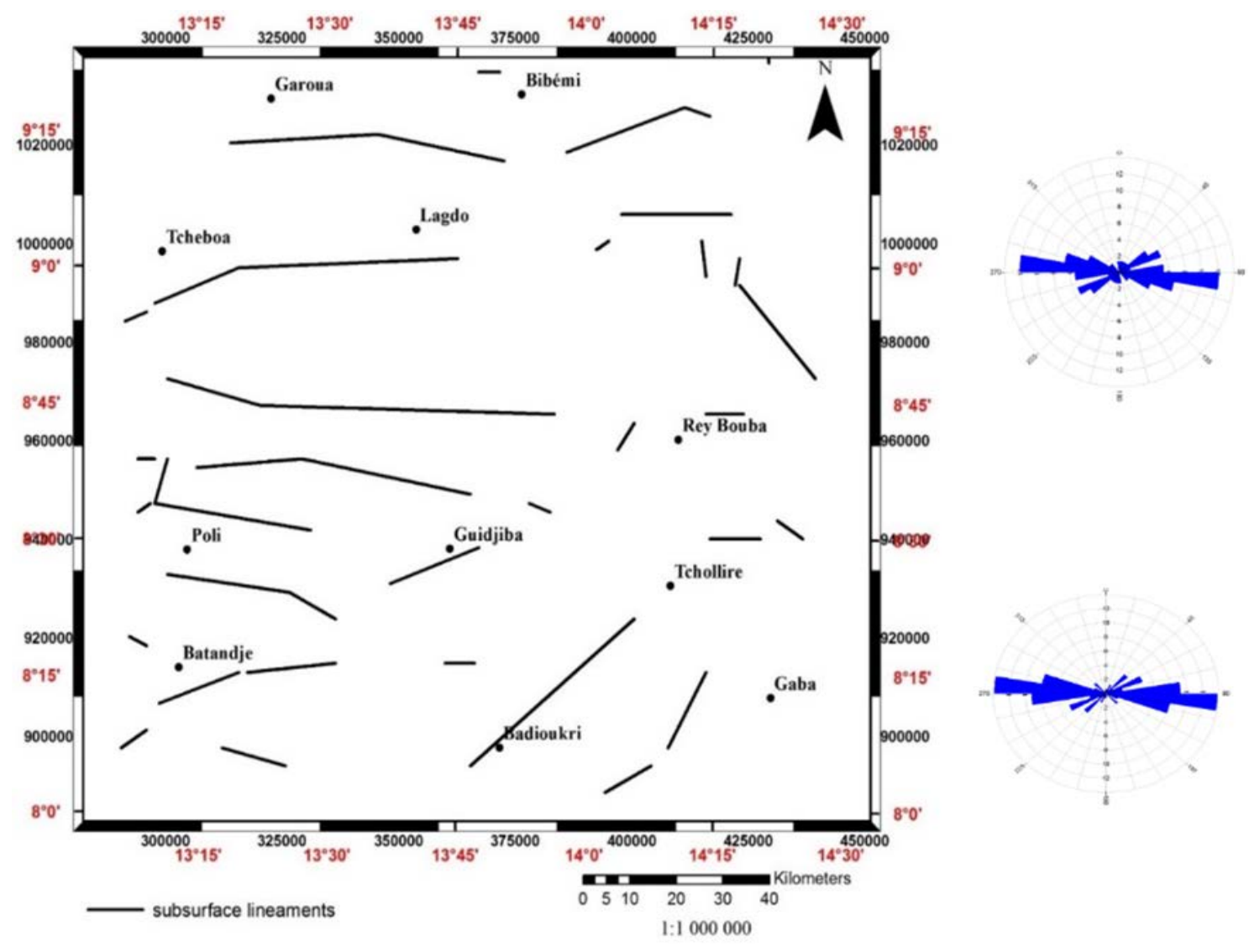

Figure 13. Major subsurface lineaments of the area 


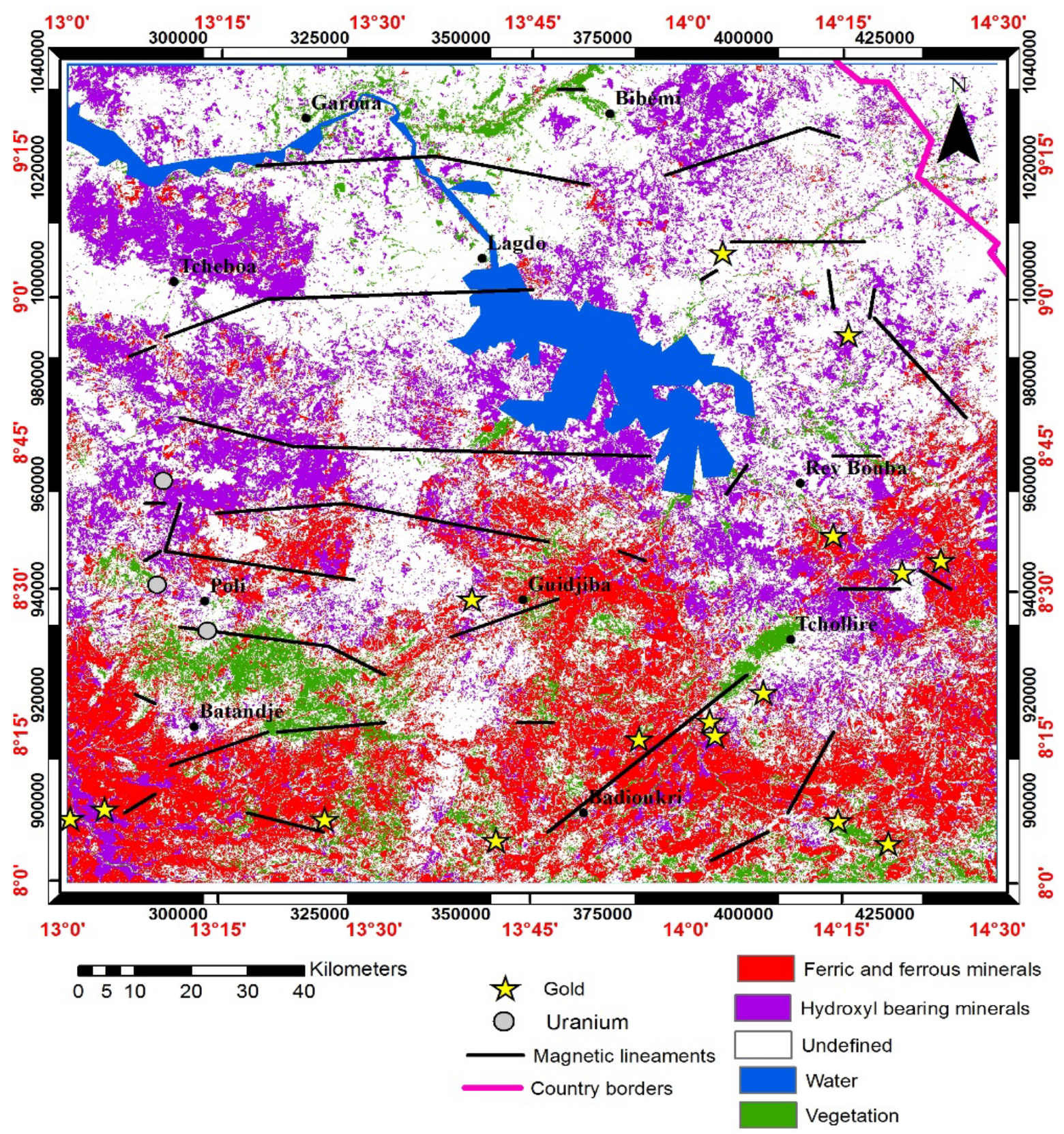

Figure 14. Target exploration map

However, it is noteworthy to mention that not all ore bodies are accompanied by alteration; i.e. alteration may not be associated with mineralization. Indeed, known hydrothermal mineralizations of the study area are hosted by granites $[10,11]$. Hence, our approach in this study must be combined with other field investigations in other to constrain targetted mineral resources.

\section{Acknowledgements}

The author wishes to thank the Center for Geological and Mining Research in Garoua/Cameroon for all the facilities provided during the study.

\section{References}

[1] Kaufmann, H. Concepts, processing and results, International Journal of Remote Sensing. 9 (10-11), 1639-1658, 1988.
[2] Sultan, M., Arvidson, R. E., Sturchio, N. C., and Guinness, E. A. Lithologic mapping in arid regions with Landsat thematic mapper data: Meatiq dome, Egypt, Geological Society of America Bulletin, 99(6), 748, 1987.

[3] Sabins, F.F. Remote sensing for mineral exploration, Ore Geology Review, 14, 157-183, 1999.

[4] Abate Essi, J.M., Yene Atangana, J.Q. Interpretation of gravity data derived from the Earth Gravitational Model EGM2008 in the Center-North Cameroon: structural and mining implications, Arab J Geosci 10: 130, 2017.

[5] Mouzong, M. P., Kamguia, J., Nguiya, S., Shandini, Y., Manguelle-Dicoum, E. Geometrical and structural characterization of Garoua sedimentary basin, Benue Trough, North Cameroon, using gravity data, J Biol Earth Sci, 2014, 4(1): E25-E33, 2014.

[6] Akame, J.M., Mvondo Ondoa, J., Assatse, T.W., Owona, S., Olinga, J.B, Messi, O.E.J., Ntomba, S. Apport des images Landsat7 ETM+ à l'étude structurale du socle archéen de Sangmélima (Sud-Cameroun), Revue Française de Photogrammétrie et deTélédétection, 206, 15-25, 2014.

[7] Takodjou Wambo, J.D., Ganno S., Afahnwie, N.A., Nomo, N.E., Mvondo, O.J., and Nzenti, J.P. Use of Landsat 7 ETM+ Data for the Geological Structure Interpretation: Case Study of the Ngoura 
Colomines Area, Eastern Cameroon, Journal of Geosciences and Geomatics, vol. 4, no. 3: 61-72, 2016.

[8] Binam Mandeng, E.P., et al. Lithologic and structural mapping of the Abiete-Toko golddistrict in southern Cameroon, using Landsat 7 ETM+/SRTM, C. R. Geoscience, 2018.

[9] Mwaniki, M. W., Moeller, M. S., and Schellmann, G. A comparison of Landsat 8 (OLI) and Landsat 7 (ETM+) in mapping geology and visualising lineaments: A case study of central region Kenya, ISPRS - International Archives of the Photogrammetry, Remote Sensing and Spatial Information Sciences, XL-7/W3, 897903, 2015.

[10] Embui, V.F., Omang, B.O., Che, V.B., Nforba, M.T., Suh, E.C. Gold grade variation and stream sediment geochemistry of the Vaimba-Lidi drainage system, northern Cameroon (West Africa), Nat Sci 5: 282-290, 2013.

[11] Kouske, A.P., Suh, C.E., Ghogomu, R.T., Ngako V. Nametasomatism and uranium mineralization during a two-stage albitization at Kitongo, northern Cameroon: structural and geochemical evidence, International J Geosc 3: 258-279, 2012.

[12] Abdelsalam, G.M., Liégeois, L., and Stern, R.J. The Saharan Metacraton, Journal of African Earth Sciences 34, 119-136, 2002.

[13] Toteu, S.F., Penaye, J., Poudjom Djomani, Y.H., Geodynamic evolution of the pan-African belt in Central Africa with special reference to Cameroon, Can J Earth Sci 41:73-85, 2004.

[14] Penaye, J., Kröner, A., Toteu, S.F., Van Schmus, W.R., Doumnang, J.C. Evolution of the Mayo Kebbi region as revealed by zircon dating: an early (ca. $740 \mathrm{Ma}$ ) pan-African magmatic arc in southwestern Chad, J Afr Earth Sci 44:530-542, 2006.

[15] Pinna, P., Calvez, J.Y., Abessolo, A., Angel, J.M., MekoulouMekoulou, T., Mananga, G., Vernhet, Y. Neoproterozoic events in the Tcholliré area, pan african crustal growth and geodynamics in central-northern Cameroon (Adamawa and north provinces). Afr Earth Sci (4):347-353, 1994.

[16] Njel, U.O. Paléogéographie d'un segment de l'orogenèse panafricaine: la ceinture volcano-sédimentaire de Poli (Nord Cameroun). C R Acad Sci Paris 303:1737-1742, 1986.

[17] Toteu, S.F., Penaye, J., Deloule, E., Van Schmus, W.R., Tchameni, R. Diachronous Evolution of Volcano- Sedimentary Basins North of the Congo Craton, Insights from U-Pb ion Microprobe Dating of Zircons from the Poli, Lom and Yaounde' Groups (Cameroon), Afr Earth Sci (44): 428-442, 2006.

[18] Toteu, S.F., Penaye, J., Deschamps, Y., Maldan, F., Nyama Atibagoua, B., Bouyo, H.M., Sep, N.J., Mbola, N.S.P. Géologie et ressources minérales du Cameroun 1/1.000.000. 33rd International Congress, Oslo, Norway, 6-14 August 2008.

[19] Benkhelil, J. Structure and Geodynamics Evolution of the intracontinental Benue-Trough (Nigeria), Thesis, University of Nice, Pub Elf (Nigeria) Ltd. 202 p, 1986.

[20] Schwoerer, P. Carte géologique de reconnaissance du Cameroun au 1/500000ème. Feuille NC 33 SO 053 Garoua-Est avec notice explicative, Publication de la Direction des Mines et de la Géologie du Cameroun. Imprimerie Nationale, Yaoundé Cameroun, 1962.

[21] Pinna, P., Edimo, A., Jézéquel, J., Tchountchoui, D., EbotayukEbop, M. Inventaire minier du Centre-Nord Cameroun, (troisième phase). Open-file Report 88 CMR 168. Bureau de Recherches Géologiques et Minières, France. 173p, 1989.

[22] Maus, S., et al. EMAG2: A 2-arc min resolution Earth Magnetic Anomaly Grid compiled from satellite, airborne, and marine magnetic measurements, Geochem, Geophys, Geosyst., 10, Q08005, 2009.

[23] Abrams, M.J., Brown, D., Leple, L., and Sadowski, R. Remote sensing of porphyry copper deposits in Southern Arizona, Economic Geology, 78, pp.591 -604, 1983.

[24] Ali, E. A., El Khidir, S. O., Babikir A. A., and Abdelrahnam, E. M. Landsat ETM+7 Digital Image Processing Techniques for Lithological and Structural Lineament Enhancement: Case Study Around Abidiya Area, Sudan, The Open Remote Sensing Journal, 5(1), 83-89, 2012.

[25] Abdelkareem, M., Othman, I., Kamal El Din G. Lithologic Mapping using Remote Sensing Data in Abu Marawat Area, Eastern Desert of Egypt, International Journal of Advanced Remote Sensing and GIS, Volume 6, Issue 1, pp. 2171-2177, 2017.

[26] Crosta, A.P, And Moore, J. McM. Enhancement of Landsat Thematic Mapper imagery for residual soil mapping in SW Minas Gerais State Brazil: a prospecting case history in greenstone belt terrain. Proceedings of the 9th Thematic Conference on Remote Sensing for Exploration Geology, Calgary (Ann Arbor, MI: Environmental Research Institute of Michigan), pp. 1173-1187, 1989.

[27] O'leary, D. W., Freidman, J. D., and Pohn, H. A. Lineament, linear, lineation: Some proposed new definitions for old terms, Geol. Soc. Am. Bull. 87 1463-1469, 1976.

[28] Phillips, J.D. Processing and interpretation of aeromagnetic data for the Santa Cruz Basin - Patahonia Mountains area, southCentral Arizona, U.S. Geological Survey Open-File Report, Arizona, pp 02-98, 1998.

[29] Tchameni, R., Doumnang, J.C., Deudibaye, M., Branquet, Y. On the occurrence of gold mineralization in the Pala Neoproterozoic formations, south-western Chad. Afr Earth Sci 84:36-46, 2013.

[30] Geosoft Incorporation. OASIS Montaj Version 8.4 User Guide, Geosoft Incorporated, Toronto, 2015.

[31] Salem and Ravat. A combined analytic signal and Euler method (AN-EUL) for automatic interpretation of magnetic data, GEOPHYSICS, VOL. 68, NO. 6; P. 1952-1961, 2003.

[32] Van Schmus, W.R., Oliveira, E.P., Da Silva Filho, A.F., Toteu, S.F., Penaye, J., Guimães, I.P. Proterozoic links between the Borborema Province, NE Brazil, and the Central African Fold Belt. J Geol Soc Lond 294:69-99, 2008. 